\title{
Comparative Analysis of Nigeria and Malaysia's Production Sharing Contract (PSC)
}

\author{
Victor D. Ola, Azubuike H. Amadi, Raphael Okeke and Paul O. Okafor
}

\section{ABSTRACT}

The oil and gas industry is governed by policies with the aim of smoothening the business relationship between the Government, the International Oil Companies (IOC's) and the Host communities. Different oil producing countries have their own laws governing petroleum activities and these laws vary from country to country based on the B-PEST factors which are Biological, Political, Environmental, Social and Technology. However, reserve size and oil type can also influence petroleum laws. Countries like Nigeria relies strongly on petroleum bills such as the PIB in which this research will be analyzing the Production Sharing Contract (PSC) which is a significant subset of the PIB. Comparison between the existing PSC of Malaysia and that of Nigeria was captured in this research and the analysis of the PSC was done based on the Government Take, National Oil Company (NOC) and the Contractor's benefits. 26.67\% and $\mathbf{5 6 . 5 8 \%}$ recovery cost, $28.67 \%$ and $\mathbf{2 6 . 2 8 \%}$ Government revenue, $\mathbf{2 3 . 1 4 \%}$ and $\mathbf{7 . 6 4 \%}$ NOC share, $21.52 \%$ and $9.50 \%$ Contractor share of revenue per barrel was arrived at for Malaysia and Nigeria respectively, showing that the Malaysian PSC model yields more income to the country when compared to that of Nigeria without necessarily short-changing the contractors or the IOCs. Finally, the reasons behind these deficits were highlighted and recommendations made to improve the PSC and benefits for all parties to the contractual agreements.

Keywords: PSC, PIB, IOC, NOC, B-PEST, Fiscal policy, Royalty, Tax, Revenue to Cost Ratio, R/C, OPEX, Cost Oil, Profit Oil.
Published Online: January 7, 2021

ISSN: 2507-1076

DOI: $10.24018 /$ ejbmr.2021.6.1.678

\section{Victor D. Ola}

Institute of Petroleum Studies, University of Portharcourt, Nigeria.

(e-mail: olavictord@ gmail.com)

Azubuike H. Amadi *

World Bank Africa Center of Excellence in Oilfield Chemical Research, University of Portharcourt, Nigeria.

(e-mail: azubuikehopeamadi@gmail.com) Raphael Okeke

Institute of Petroleum Studies, University of Portharcourt, Nigeria.

(e-mail: okekeraphael@yahoo.com)

Paul O. Okafor

Institute of Petroleum Studies, University of Portharcourt, Nigeria.

(e-mail: paultwizzy21@ gmail.com)

*Corresponding Author

\section{INTRODUCTION}

The oil and gas industry as it is today, takes the major lead of the energy industry in the provision for the day to day energy requirements of the whole wide world. The oil and gas industry are a sector that seeks to meet people's demand for energy in an atmosphere of business culture, where investors are expected to make profit. Oil and gas are an internationally traded commodity with domineering interplay of politics and economics to determine its investment, price policies, production, and trade [8].

By the virtue of the UN Geneva convention of 1958, states are granted the sovereignty over the ownership of its territory, adjourning waters and continental shelf. Four years later on 14th of December 1962, the United Nations General Assembly (UNGA) through one of its commission on Permanent Sovereignty on Natural Resources declared the permanent sovereignty of nations over their natural resources. This instituted a system where the exploitation of such minerals was subject to domestic laws in the guidance of policies and legal actions as it is fitting to any state's developmental interest. Excluding the United States of America, international law attaches the ownership of mineral resources to the sovereignty of a state [16].

In lieu of this, it therefore becomes imperative that oil and gas as a mineral is vested by ownership either to government or individuals according to the law of the state where it exists. But due to its lucrative value in the international market, its environmental impact, and its diminishing nature because of production over time, it therefore needs to be subject to different laws and regulations in its operation.

In order to derive maximum value from its extraction and use, government of many nations in whose territory this mineral is found have therefore subjected its operations to many business, policies, and legal framework to derive maximum efficiency and effectiveness. As a result, acquisition of mineral interest in property before oil and gas exploration, prospecting, production, and operation of petroleum activities are required [9]. This birthed some fiscal arrangement in the dealings of the industry. The oldfashioned concessionary arrangements and contractual arrangements, terms used to describe the operational arrangements needed to keep both investors, government, and the people of the state happy in a win - win situation. Among these fiscal arrangements are Joint Venture, Production Sharing Contracts, Farm In, Farm Out, Carried interest, etc.

In government policy formulation, there are different techniques used to generate her own economic rent and benefit. They may include collection of bonuses, corporate tax, royalty rate, cost recovery, export duty, domestic 
market supply amongst others [12]. It must be stated that the approach to fiscal regime depends largely on the host state's priorities towards her development and a need to attract foreign investment into the country.

\section{Brief History OF Petroleum CONTRACTS}

There are four basic contract types - Production Sharing Agreements, Joint Ventures, Service Contract and Concessions. Each one differs from the other by the compensation arrangements, levels of involvement by the NOCs, and control levels granted to the foreign company [4]. Whichever method is adopted, they all are there to achieve the same purpose of development of the country's mineral resources, generate revenue to the government and make profit for the foreign companies.

In Fig. 1 below, a tree summary of the fiscal arrangements available in the oil and gas industry is represented.

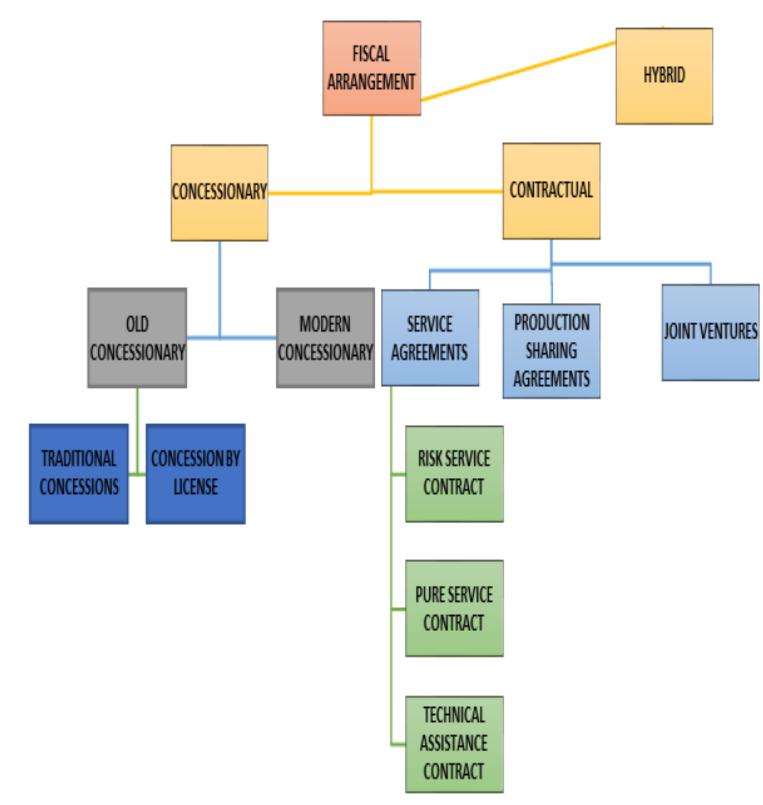

Fig. 1. Fiscal arrangements available in the oil and gas industry [16].

In the Fig. 2 below, the 2018 data for Nigeria's different contract lease type is shown with Production Sharing Contract (PSC) taking the lead amongst them, closely followed by Joint Venture, Sole Risk and Service Contract in that descending order.

\section{FISCAL ARRANGEMENT BY \%}

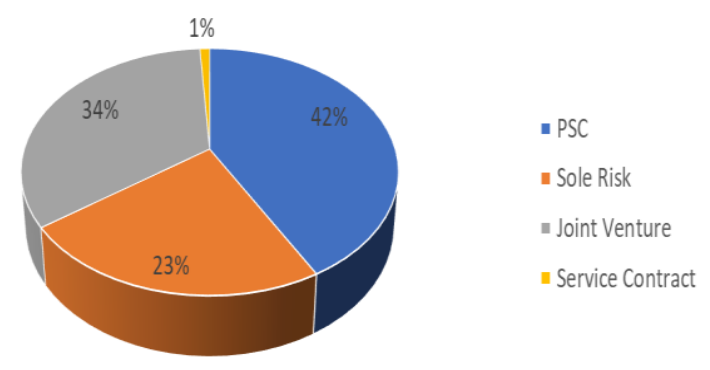

Fig. 2. Nigeria's concession by lease contract type [3].

\section{PRODUCTION-SHARING CONTRACT (PSC)}

What production-sharing contract (PSC) implies is that the oil company bears the whole cost of exploration, development, and operation while it recovers its cost when oil is found and shares the profit according to a sharing ratio with the government through her national oil company.

This is the type of contract arrangement where the concession holder (e.g., the Nigerian National Petroleum corporation, NNPC or PETRONAS or PETROBRAS) allows the oil company to bring in its capital, equipment, and technology to explore and exploit oil and gas resources, with the agreement to recover its investment and share the profit or reward with the host national company (or concession holder). It must be noted that in this form of arrangement, the host national company takes no risk or a minimal risk in the development of the field.

The term came to be heard of in early 1960s when Indonesia as an oil producing state adopted its use for petroleum exploration and development in its territories [5]. The features of a production sharing contract have not been universally agreed upon yet, however, each country designs it to suit its major needs [15].

Most developing countries producing oil use the Production Sharing Contract for its operation as it gives a feel of sovereignty over the petroleum resources in their domain [16]. While many countries have adopted it for quite a large portion of their onshore and offshore field development, Nigeria only adopted it for the exploration and development of Deep Offshore and Inland Basins [9].

Fig. 3 below is a hierarchical diagram which shows the basic features commonly found in a Production Sharing Contract. The boxes in grey indicates the government's share while that in red indicates the foreign company's share of the oil/gas produced.

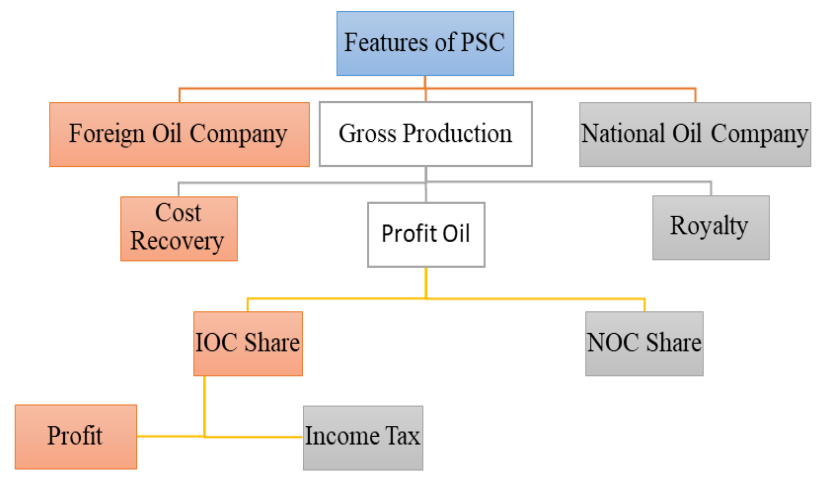

Fig. 3. Features of a Production Sharing Contract (PSC) [4].

A simple arithmetic is shown in the Fig. 4 below to further elucidate the concept of Production Sharing Contract. 


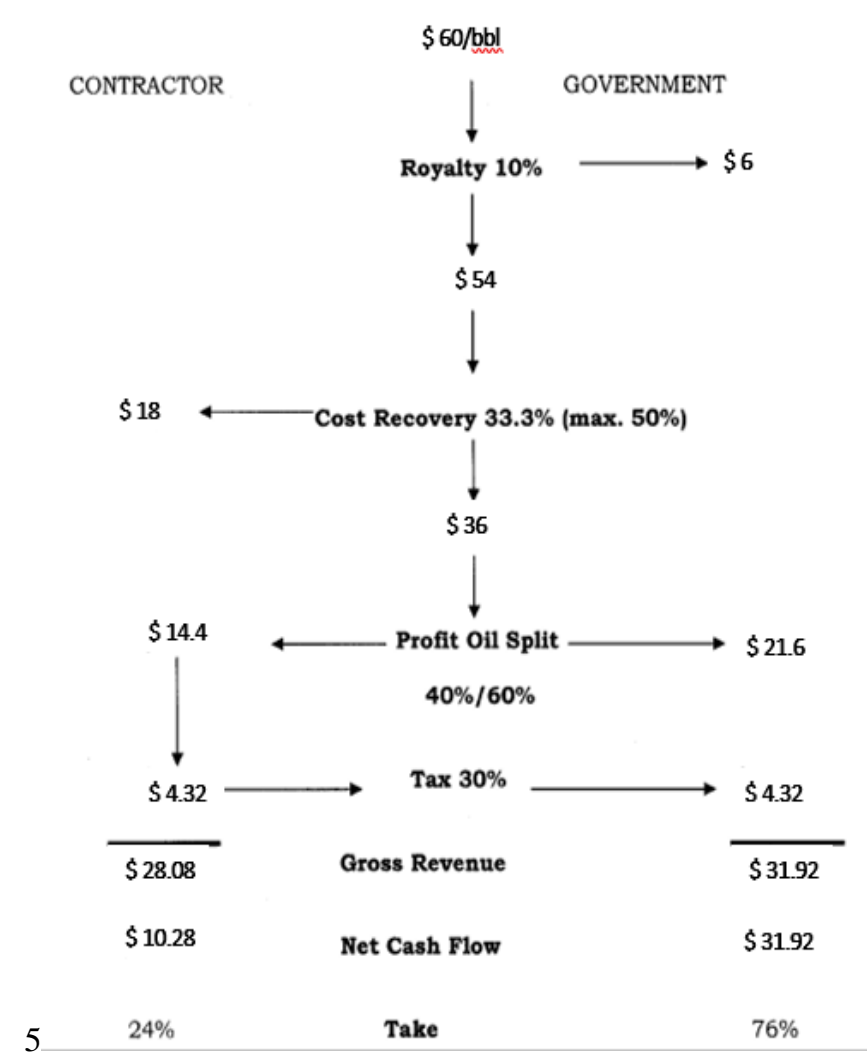

Fig. 4. A flowchart showing a simple arithmetic figures of a typical PSC structure [4].

\section{IMPLICATIONS OF A PSC}

Also, McMichael et. al. noted that each country establishes a PSC based on their sovereign needs, which implies that PSC is specific (this may imply it is fixed permanently) and changes from country to country. They further explained that such contracts provide technical guidance for a company's proven reserve and little guidance to help a company book a reserve [6]. Opus Kinetic established six (6) features of a PSC namely Parties, Relinquishment clause, National interest provisions, carry provisions, profit oil and cost recovery oil, which significantly affects the contractual agreements [11]. This implies that a PSC presents a medium for the government to sustain exploration, development, and production of its resources for maximum benefits. A critical advantage of PSC is the ability of learning from IOC's in decision making and technology, also, the risk of the host country is lowered when PSC's are applied [15]. Liu et. al. reiterated that a royalty and income tax is commonly imposed on the IOC's for operations in such territory even after the cost oil and profit oil are being split between NOC and IOC [5]. The PSC is the base of fiscal policy in the oil and gas industry and needs to be treated with a high sensitivity as its policies has a long term and short-term impact on economies [1].

\section{MALAYSIAN PRODUCTION SHARING CONTRACT}

The Malaysian Production Sharing Contracts PSC has 3 subdivisions for its fiscal terms. This subdivision is based on water depth. They are:

1. $20 \mathrm{~m}-200$ Metres.

\section{2. $200 \mathrm{~m}-1000$ Metres.}

\section{3. > 1000 metres}

Malaysia carries out its exploration, development and production activities through its National Oil Company, Petronas, having Production Sharing Contracts (PSC) with several international and indigenous oil and gas companies and with its wholly owned subsidiary, Petronas Carigali Sendirian Berhad (PCSB). It is governed by the country's Petroleum Development Acts of 1974 which vested ownership of petroleum resources into Petronas, established by Petroleum Income Tax Act of 1967, as well as the Petroleum Income Tax Amendment Act of 1976. In 1997, a new PSC based on the "revenue over cost" concept (the R/C PSC) was introduced to encourage additional investment in Malaysia's upstream sector. The R/C PSC allows PSC Contractors to accelerate their cost recovery if the contractors achieved certain cost targets. The basic principle of R/C PSC is to allow the PSC Contractors a higher share of production when the Contractor's profitability is low and to increase Petronas share of production when Contractor's profitability improves. The contractor's profitability is measured by "R/C Index", which is the ratio of contractor's cumulative revenue over contractor's cumulative costs [12]. This type of calculation is based on rate or volume of production and not profitability.

The Table 1 and Table 2 below shows the main features of Malaysia's Revenue-to-Cost (R/C) PSC concept otherwise referred to as the sliding $\mathrm{R}$-factor.

TABLE 1: MALAYSIA FISCAL TERM AND FIGURES ASSOCIATED [13]

\begin{tabular}{cc}
\hline \hline \multicolumn{2}{c}{ Malaysian Model } \\
\hline \hline Fiscal Term & Features \\
\hline Royalty & $10 \%$ \\
Petroleum Income Tax & $38 \%$ \\
Export Duty & $10 \%$ \\
Research Levy & $0.5 \%$ \\
Petronas Carigali's Interest & $20 \%$ \\
Exploration Period & 5 Years \\
Gas Holding Period & 5 Years \\
Development Period & 4 Years \\
Production Period & 20 Years \\
\hline \hline
\end{tabular}

In Table 2 below is shown the Revenue to Cost Ratio of the PSC fiscal term of the Malaysian oil and gas industry.

TABLE 2: MALAYSIAN R/C PSC TABLE [10]

\begin{tabular}{cccc}
\hline \hline \multirow{2}{*}{$\begin{array}{c}\text { Contractor's R/C } \\
\text { Ratio }\end{array}$} & Cost Oil & \multicolumn{2}{c}{ Profit Oil } \\
\cline { 2 - 4 } & $\begin{array}{c}\text { Cost Oil } \\
\text { Ceiling }\end{array}$ & $\begin{array}{c}\text { Unused Cost } \\
\text { oil PET: CONT }\end{array}$ & $\begin{array}{c}\text { Profit Oil } \\
\text { PET: CONT }\end{array}$ \\
\hline $0.0<\mathrm{R} / \mathrm{C}<=1.0$ & $70 \%$ & Not Applicable & $20: 80$ \\
$1.0<\mathrm{R} / \mathrm{C}<=1.4$ & $60 \%$ & $20: 80$ & $30: 70$ \\
$1.4<\mathrm{R} / \mathrm{C}<=2.0$ & $50 \%$ & $30: 70$ & $40: 60$ \\
$2.0<\mathrm{R} / \mathrm{C}<=2.5$ & $30 \%$ & $40: 60$ & $50: 50$ \\
$2.5<\mathrm{R} / \mathrm{C}<=3.0$ & $30 \%$ & $50: 50$ & $60: 40$ \\
$\mathrm{R} / \mathrm{C}>3.0$ & $30 \%$ & $60: 40$ & $70: 30$ \\
\hline \hline
\end{tabular}

The Fig. 5 below shows a representation of the split of a barrel of oil in the Malaysian PSC model. 


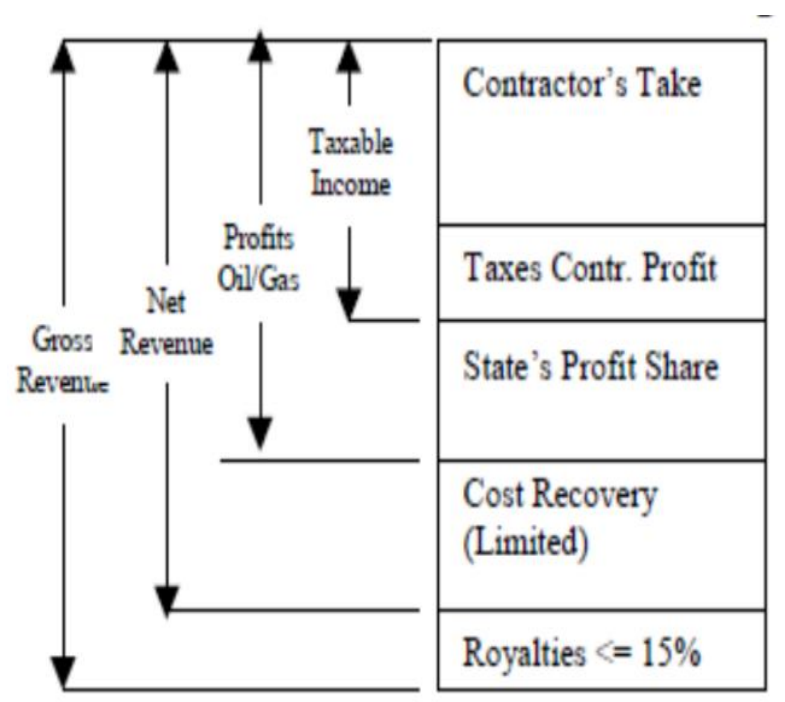

Fig. 5. A Barrel of Oil Split in Malaysian PSC [10]

The Table 3 below illustrates and further explains the relationship between the contractor's net cash flow and the revenue generated from oil production.

TABLE 3: REVENUE ACQUISITION IN MALAYSIA OIL AND GAS PSC

\begin{tabular}{ccc}
\hline \hline \multicolumn{3}{c}{ Revenue Acquisition in Malaysia } \\
\hline \hline GOVERNMENT & NOC & CONTRACTOR \\
\hline Royalty + Tax from NOC and & \% from & $\%$ from Profit + Cost Oil \\
Contractor & Profit Oil & Recovery \\
\hline \hline
\end{tabular}

Contactor's Net Cash Flow $=$ Revenue - Costs Government Intake

The Fig. 6, and Fig. 7 below shows what is applicable to the Malaysian PSC model using water depth as a reference point.

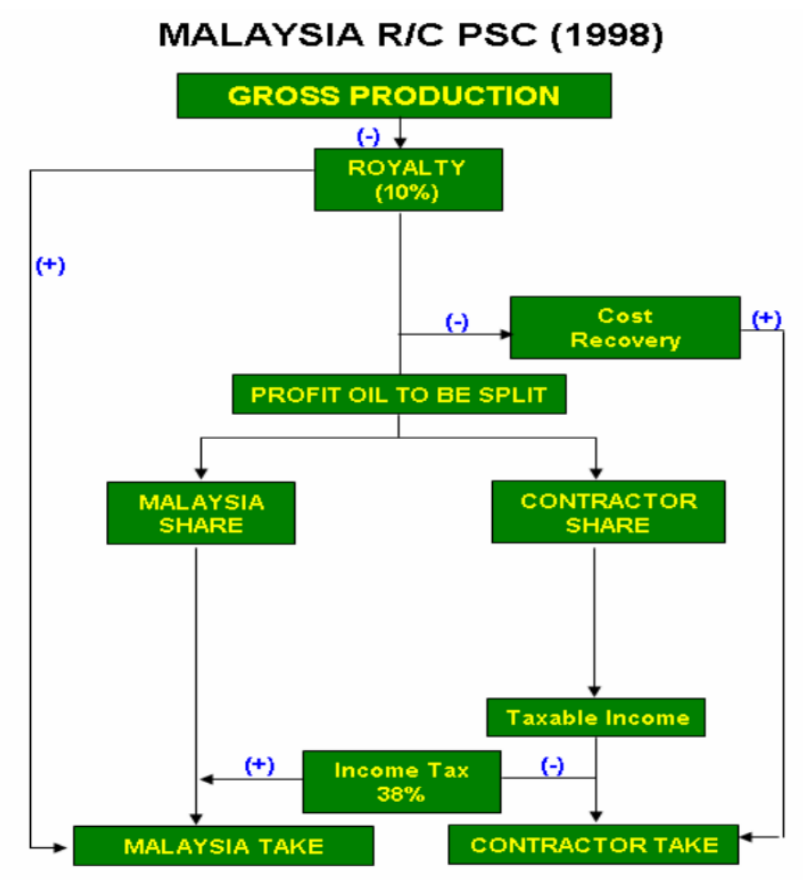

Fig. 6. Malaysia R/C PSC (20m - 200 Metres of Water Depth) [12].

\section{Malaysia Deepwater (200-1000m) Production Sharing Contract}

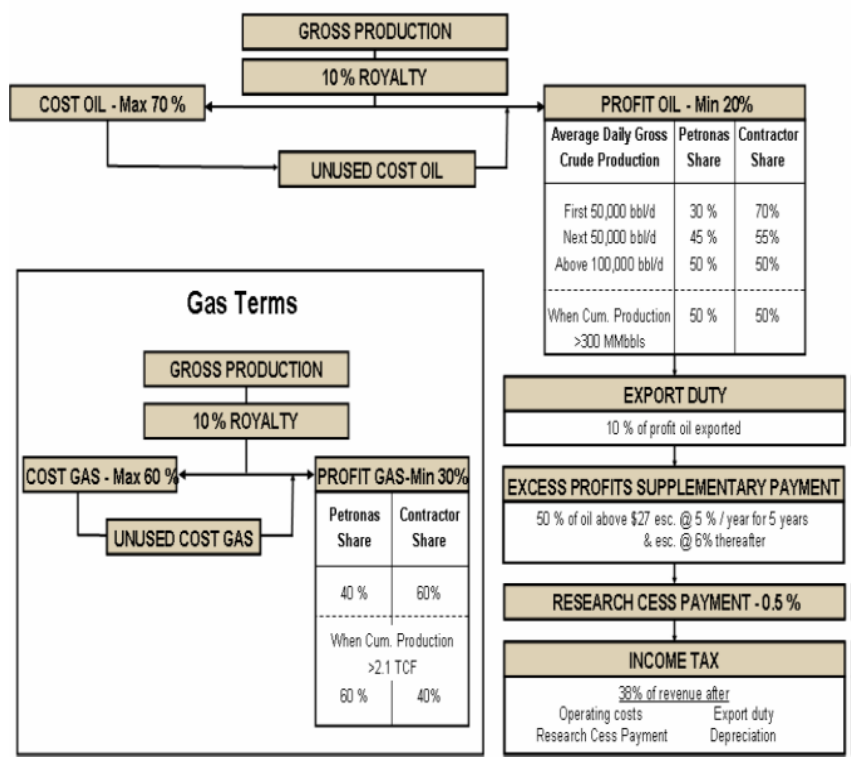

Fig. 7. Malaysia PSC (200 - 1000 Metres of Water Depth) [12].

Furthermore, we should note that the Malaysian PSC does not require the payment of bonuses - signature and discovery as it has been waived.

In conclusion, the Malaysian state through its Petroleum Development Act (PDA) of 1974 vested its petroleum resources into Petronas, its national oil company in order to affirm the full control of the management and regulations of its oil minerals and its entire value chain [14]. A change in the terms of the PSC from 1976, to 1985, and Revenue over Cost $(\mathrm{R} / \mathrm{C})$ shows that it is in charge of its revenue collection accruing from the production of oil and gas while giving the contractors (IOCs) chance to recoup their investment and make reasonable profits. That way they have a sense of not being cheated as seen in the concessionary system of fiscal arrangement initially adopted during the colonial era. We can emphatically say that the Malaysian PSC is designed in such a way that the country stipulates the role and responsibility of the contractors while it benefits most out of a barrel of crude produced.

\section{Nigerian Production SHARING CONTRACT}

The Nigerian development of oil fields using Production Sharing Contracts has taken a different form over the years. Its first mention was in 1973 for developing two Oil Prospecting License (OPLs) with discouragement to further use it arising due to various renegotiations of its terms. However, the early 1990s saw its reappearance for new award of acreages for oil development [15].

The Table 4 below highlights the features of PSCs in Nigeria from 1973 to 2005. 
TABLE 4: HISTORICAL COMPARISON OF NIGERIAN PSC MODEL [14]

\begin{tabular}{|c|c|c|c|c|}
\hline \multirow{2}{*}{ Features } & \multicolumn{4}{|c|}{ Years } \\
\hline & 1973 & 1993 & 2000 & 2005 \\
\hline Acreage & Inland Basin & $\begin{array}{l}\text { Deep Offshore and } \\
\text { Inland Basin }\end{array}$ & $\begin{array}{l}\text { Deep Offshore and } \\
\text { Inland Basin }\end{array}$ & $\begin{array}{l}\text { Deep Offshore and Inland } \\
\text { Basin }\end{array}$ \\
\hline \multirow{3}{*}{$\begin{array}{l}\text { Initial Term } \\
\text { Management Committee }\end{array}$} & 20years +5 added & $25-30$ years & $25-30$ years & $25-30$ years \\
\hline & None & Yes (10) & Yes (10) & Yes (10) \\
\hline & & $\begin{array}{l}5 \text { from contractor, } 5 \\
\text { from NNPC }\end{array}$ & $\begin{array}{l}5 \text { from contractor, } 5 \\
\text { from NNPC }\end{array}$ & $\begin{array}{l}5 \text { from contractor, } 5 \text { from } \\
\text { NNPC }\end{array}$ \\
\hline $\begin{array}{l}\text { Production Premiums } \\
\text { (Recoverable as OPEX) }\end{array}$ & Yes (Yes) & No & No & No \\
\hline Cost Oil Limit & Infinity & $60-80 \%$ & $60-80 \%$ & $60-80 \%$ \\
\hline Tax Oil & $55 \%$ & & & \\
\hline Profit Contractor & $35 \%$ & Production Based & Production Based & Production Based \\
\hline NNOC & $65 \%$ & & & \\
\hline Title to Oil & At Wellhead & At Export & At Export & At Export \\
\hline Production Bonus & None & Yes & Yes & Yes \\
\hline Signature Bonus Payment & None & $\begin{array}{l}\text { Effective Date of } \\
\text { Contract }\end{array}$ & $\begin{array}{l}\text { Paid within } 30 \text { days } \\
\text { of Contract }\end{array}$ & Before execution of Contract \\
\hline $\begin{array}{l}\text { Clause for economic } \\
\text { Amendments }\end{array}$ & None & Yes & Yes & Yes \\
\hline Minimum Work Program & None & $\begin{array}{l}\text { 3-phase minimum with } \\
\text { no stipulated amount } \\
\text { to be expended }\end{array}$ & $\begin{array}{l}\text { 2-phase minimum } \\
\text { with no stipulated } \\
\text { amount to be spent }\end{array}$ & $\begin{array}{l}\text { 2-phase minimum with } \\
\text { stipulated minimum amount } \\
\text { to be expended }\end{array}$ \\
\hline $\begin{array}{l}\text { Parent Company/Corporate } \\
\text { Guarantor }\end{array}$ & None & None & None & Required \\
\hline $\begin{array}{l}\text { Submission of Technical and } \\
\text { Economic Data to NNPC }\end{array}$ & No & No & Yes & Yes \\
\hline $\begin{array}{l}\text { Conversion of OPL to OML in } \\
\text { Contract Area } \\
\text { New PSC for another OML to } \\
\text { that single OPL }\end{array}$ & $\begin{array}{l}1 \text { OPL to many } \\
\text { OMLs }\end{array}$ & $1 \mathrm{OPL}$ to many OMLs & $\begin{array}{l}1 \text { OPL to many } \\
\text { OMLs }\end{array}$ & $1 \mathrm{OPL}$ to $1 \mathrm{OML}$ \\
\hline Downstream Projects & No Obligations & No Obligations & No Obligations & $\begin{array}{l}\text { Must undertake a supporting } \\
\text { downstream project }\end{array}$ \\
\hline Non-Gratification Clause & None & None & None & Yes \\
\hline
\end{tabular}

A real-life example for a PSC Contract awarded 2002 which is subject to the PSC features of 2000 is briefly highlighted below. The main content contains the following:

1. Signature Bonus: (\$210million dollars)

a. \$1 million dollars to Federal Government of Nigeria PDTF account within 30days of contract execution.

b. \$209 million dollars to Escrow account within 5days of Escrow Agreement.

2. Production Bonus: 100,000 barrels or cash equivalent to be paid within 30 days of production level attainment at

a. 50 million barrels.

b. 100 million barrels.

These two bonuses are not recoverable as part of cost oil.

3. Duration for the contract:

a. OPL - 10years.

b. OML - 20years.

4. Profit Oil Table.

TABLE 5: PROFIT OIL PERCENTAGES FOR A PSC AWARDED IN 2002 [7]

\begin{tabular}{ccc} 
Cumulative Production in MM & Profit Oil Percentages \\
\cline { 2 - 3 } Barrels from Contract Area & Contractor & Corporation \\
\hline $0-350$ & 70 & 30 \\
$351-750$ & 65 & 35 \\
$751-1000$ & 52.5 & 47.5 \\
$1001-1500$ & 45 & 55 \\
$1501-2000$ & 35 & 65 \\
$>2000$ & Negotiable & \\
\hline
\end{tabular}

The Deep Offshore and Inland Basin Production Sharing Contract Act of 1999 which is the latest adopted Act for PSC is, an Act to, among other things, give effect to certain fiscal Incentives designated to the oil and gas companies operating in the Deep Offshore and Inland Basin areas under production sharing contracts between the Nigerian National
Petroleum Corporation (NNPC) or other companies holding oil prospecting licenses or oil mining leases and various petroleum exploration and production companies [2]. Over the years, it has gone through several adjustments to enable maximum benefits to the nation.

Notwithstanding anything to the contrary contained in any other enactment or law, the provisions of this Act shall apply to all production sharing contracts as defined in section 17 of this Act.

\section{A. Duration of oil prospecting licenses}

According to the Act establishing the PSC, the duration of an oil prospecting license relating to production sharing contracts in the Deep Offshore and Inland Basin shall be determined by the Minister and shall be for a minimum period of five years and an aggregate period of ten years.

\section{B. The Sharing Formula}

This entails the format for profit sharing between the nation state and the contractor willing to go into agreement with her.
a) Bonuses - Signature, Discovery, Production.
b) Cost oil/Recovery oil.
c) Royalties.
d) Profit oil.
e) Taxes.

\section{Determination of Petroleum Profit Tax}

a. The petroleum profits tax payable under a production sharing contract shall be determined in accordance with the Petroleum Profits Tax Act: Provided that the petroleum profits tax applicable to the contract area as defined in the production sharing contracts and shall be 50 per cent flat rate of chargeable profits for the duration of sharing 
production sharing contracts

b. Nothing contained in this Act shall be construed as having exempted the contractors from the payment of any other taxes, duties or levies imposed by any Federal, State or Local Government, or Area Council Authority.

\section{Determination of Investment Tax Credit and Investment} Tax Allowance

a. Where the Nigerian National Petroleum Corporation (in this Act referred to as "the Corporation") or the holder and the contractor have incurred any qualifying capital expenditure wholly, exclusively and necessarily for the purposes of petroleum operations carried out under the terms of a production sharing contract in the Deep Offshore or Inland Basin, there shall be due to the parties in respect of the production sharing contracts executed prior to 1 July 1998, a credit (in this Act referred to as "investment tax credit") at a flat rate of 50 per cent of the qualifying expenditure in accordance with the production sharing contract terms for the accounting period in which that asset was first used for the purposes of such operations.

b. In respect of parties who executed production sharing contracts after 1 July 1998 , there shall be due to such parties an allowance (in this Act referred to as an "investment tax allowance") at a flat rate of 5 percent of the qualifying expenditure in accordance with the provisions of existing applicable legislation for the accounting period in which that asset was first used for the purposes of such operations.

\section{E. Royalty Payable in Respect of Production Sharing Contracts}

The payment of royalty in respect of the Deep Offshore production sharing contracts shall be graduated as follows, that is:

\section{1) Area Rate}

1. In areas from 201 to 500 metres water depth 12 percent.

2. From 501 to 800 metres water depth 8 per cent.

3. From 801 to 1000 metres of water depth 4 percent.

4. In areas in excess of 1000 metres depth 0 per cent.

The royalty rate payable under the production sharing contracts in the Inland Basin shall be 10 per cent.

\section{2) Price Based}

On 4th November 2020, the President signed into law another amendment of the Deep Offshore and Inland production sharing contracts Act 2019 as adjusted by the national assembly. The new royalty system did a combination of production and pre-based royalty to replace production-based royalty system. The graduated royalty rates are shown below:

1. from $\$ 0$ up to $\$ 20$ per barrel $0 \%$.

2. above $\$ 20$ and up to US $\$ 602.5 \%$.

3. above $\$ 60$ and up to US $\$ 1004.0 \%$.

4. above $\$ 100$ and up to US $\$ 1508.0 \%$.

5. above $\$ 15010.0 \%$.

In conclusion, having seen from the above study, we can deduce that the changes occurring from time to time in the terms and conditions of the Production Sharing Contract by the legislative and the executive arm of the government through the national oil company gives an indication that Production Sharing Contract gives the Nigerian government a control of her sovereignty over the petroleum resources found within her territory and as such is flexible for her to make maximum revenue from it.

\section{ECONOMIC ANALYSIS}

This calculation is made based on assumed data but represents the PSC model practiced in Malaysia and Nigeria. The purpose is to compare in order to determine that, based on the different models, which of the two countries will derive maximum benefit to the host government within whose territory the petroleum resources is found.

Assumptions Made:

1. Price of crude is $\$ 48 / \mathrm{barrel}$.

2. Production per day $=110,000$ bopd.

3. Field Location: Deep Offshore, WD $=900$ metres.

4. OPEX/barrel $=\$ 19 /$ barrel for Nigeria, $\$ 10 /$ barrel for Malaysia.

5. Cost Oil: $30 \%$ for Malaysia, $40 \%$ for Nigeria based on $\mathrm{R} / \mathrm{C}$ factor.

TABLE 6: NigERIA PSC MODEL REVENUE

\begin{tabular}{ccccccc}
\hline \hline & & \multicolumn{5}{c}{ Revenue } \\
\hline R/C=1.536 & $\begin{array}{c}\text { Value } \\
\left(\mathrm{x} 10^{6}\right)\end{array}$ & $\begin{array}{c}\text { Bal. } \\
\left(\mathrm{x} 10^{6}\right)\end{array}$ & $\begin{array}{c}\text { Cont. } \\
\left(\mathrm{x} 10^{6}\right)\end{array}$ & $\begin{array}{c}\text { NOC } \\
\left(\mathrm{x} 10^{6}\right)\end{array}$ & $\begin{array}{c}\text { Govt. } \\
\left(\mathrm{x} 10^{6}\right)\end{array}$ & $\begin{array}{c}\text { Cost Rec. } \\
\left(\mathrm{x} 10^{6}\right)\end{array}$ \\
\hline Gross Rev. & 5.28 & 5.28 & & & & \\
Royalty (2.5\% Rev.) & 0.264 & 5.016 & & & 0.264 & \\
Cost Oil (70\% max) & 2.006 & 3.010 & 2.006 & & & 2.006 \\
Profit oil (40\%C, 60\% NOC) & 3.010 & & 1.204 & 1.806 & & \\
Export Duty (10\% of CEO) & 0 & & 0 & & 0 & \\
Excess Profit (> \$27) & 0 & 0 & & & & \\
RCP (0.5\% of CC) & 0.134 & & 0.134 & & & \\
Depreciation & & & -1.020 & & & \\
Taxable Income (TI) & & & -0.867 & 1.535 & 0.668 & \\
In. Tax (38\% TI) & & & 0.337 & 0.271 & 0.932 & \\
Net C/F & & 9.50 & 7.64 & 26.28 & 56.58 \\
\% Rev/bl.
\end{tabular}


TABLE 7: MALAYSIAN PSC MODEL REVENUE

\begin{tabular}{ccccccc}
\hline \multicolumn{7}{c}{ TABLE 7: MALAYSIAN PSC MODEL REVENUE } \\
\hline R/C=2.78 & $\begin{array}{c}\text { Value } \\
\left(\mathrm{x} 10^{6}\right)\end{array}$ & $\begin{array}{c}\text { Bal. } \\
\left(\mathrm{x} 10^{6}\right)\end{array}$ & $\begin{array}{c}\text { Cont. } \\
\left(\mathrm{x} 10^{6}\right)\end{array}$ & $\begin{array}{c}\text { NOC } \\
\left(\mathrm{x} 10^{6}\right)\end{array}$ & $\begin{array}{c}\text { Govt. } \\
\left(\mathrm{x} 10^{6}\right)\end{array}$ & $\begin{array}{c}\text { Cost Rec. } \\
\left(\mathrm{x} 10^{6}\right)\end{array}$ \\
\hline Gross Rev. & 5.28 & 5.28 & & & & \\
Royalty (10\% Rev.) & 0.528 & 4.752 & & & 0.528 & \\
Cost Oil (70\% max) & 1.426 & 3.326 & 1.426 & & & 1.426 \\
Profit oil (70\%C, 30\% NOC) & 3.326 & & 1.331 & 1.996 & & \\
Export Duty (10\% of CEO) & 0.133 & & 0.133 & & 0.133 & \\
Excess Profit (> \$27) & 0.067 & & & & 0.067 & \\
RCP (0.5\% of Contractor Crude) & 0.007 & & 0.007 & & 0.007 & \\
Depreciation & 0.095 & & 0.095 & & & \\
Taxable income (TI) & & & 0.106 & & & \\
In. Tax (38\% TI) & & & 0.040 & 0.758 & 0.799 & \\
Net C/F & & & 21.52 & 23.14 & 28.67 & 26.67 \\
\% Rev/bl. & & & & & \\
\hline \hline
\end{tabular}

TABLE 8: REVENUE GENERATION USING SAME ASSUMPTIONS FOR MALAYSIAN AND NIGERIAN PSC MODELS

\begin{tabular}{ccc}
\hline \hline Stakeholder's & Malaysia & Nigeria \\
\hline Revenue & $28.67 \%$ & $26.28 \%$ \\
Government & $23.14 \%$ & $7.64 \%$ \\
NOC & $21.52 \%$ & $9.50 \%$ \\
Contractor & $26.67 \%$ & $56.58 \%$ \\
Cost Recovery & \\
\hline \hline
\end{tabular}

\section{CONCLUSION}

It has been shown form this study, the way Production Sharing Contracts seeks to give sovereignty to a country where the petroleum resources are found. The comparison made from the PSC models, proves that Malaysia generates more revenue to the government than its Nigerian counterpart, while other parties involve in its agreement receives a fair share as well. The main reason is because of the low royalty demanded for deep offshore production in Nigeria, and the high cost per barrel of producing Nigerian oil.

\section{RECOMMENDATIONS}

From the analysis on PSC covered by this work and ongoing research, the following recommendations were made on the Nigeria PSC.

1. Nigeria should review the royalty agreements for deep offshore agreements, as more oil production in place offshore means increased revenue for her.

2. The impact of the high production cost in Nigeria affected the government share during the comparison, hence, better technology should be applied to reduce OPEX.

3. To transition into a fiscal regime that generates more revenue for government while attracting more foreign investors (IOC's) to unlock deeper reserves, there is a need for robust amendment through stakeholder meetings that effectively manages the concerns of all parties involved.

4. The PSC does not address a situation of dwindling oil prices. It should have the adaptability of revising balanced fiscal conditions and guidelines between the holder and contractor when rates are very low.

\section{ACKNOWLEDGMENT}

We specially thank the Institute of Petroleum Studies (IPS), University of Port Harcourt for the lead way into this research work.

\section{REFERENCES}

[1] Azubuike A. (2020, December 14). Policy Desk [LinkedIn], Energy Lighthouse: Energy Digest. Retrieved from https://www.linkedin.com/posts/theenergylighthouse_energy-digestweek-2-activity-6744207748986093568-JPCq.

[2] Deep Offshore and Inland Basin Production Sharing Contract Act 1999 (NG.). Decree. No. 26 (Nigeria).

[3] DPR (2018). Nigerian Oil and gas industry annual report.

[4] Kirsten, B. (1999). Production Sharing Agreements; An Economic Analysis. Oxford, UK: Oxford Institute for Energy Studies.

[5] Liu M., Wang Z., Zhao L., Pan Y. and Xiao F. (2012). Production sharing contract: An analysis based on an oil price stochastic process, Petroleum Science 9(3), 408-415.

[6] McMichael C. L., McMichael and Associates, Young E. D. and Mobil Technical Center (1997). Effect of Production Sharing and Service Contracts on Reserves Reporting, Society of Petroleum Engineers, OnePetro, SPE 37959, $204-210$.

[7] NNPC (2003). PSC of OPL Block 245

[8] Nwaobi, G. (2014). Oil Policy in Nigeria: A critical assessment (1958-1992). Research Gate.

[9] Ogbonna, G. N. (2019, October). Contract Planning, Cost Estimation and Project Management. Port Harcourt, Rivers State.

[10] Ogunleye, T. A. (2015). A Legal Analysis of Producton Sharing Contract Arragements in the Nigerian Petroleum Industry. Journal of Energy Technologies and Policy.

[11] Opus Kinetic (2019, October 15). 6 features of Production Sharing $\begin{array}{llll}\text { Contracts } & \text { [Blog } & \text { post }] \text { from }\end{array}$ https://www.opuskinetic.com/2019/10/features-of-productionsharing-contracts/.

[12] Putrohari, R. D., Kasyanto, A., Suryanto, H., \& Abdul-Rasheed, I. M. (2007). PSC Term and condition and its implementation in South East Asia. Thirty-First Annual Convention and Exhibition, Indonesia: Indonesia Petroleum Association.

[13] Rozani, R., Mohd Zaki, N. I. \& Abu Husain, M. K. (2006). Cost Inflated Enigma in Upstream Petroleum Industry Projects in Malaysia. International Conference on Ocean, Mechanical and Aerospace for Scientists and Engineers. Terengganu, Malaysia: Universiti Malaysia Terengganu, Malaysia. 77 - 86.

[14] Taverne, B. (1996). Production Sharing Agreements in Principle and Practice in: M.R David (ed) Upstream Oil and Gas Arrangement. London: Sweet \& Maxwell.

[15] Taverne, B. (1999). Petroleum, Industry and Government: An Introduction to Petroleum Regulation, Economies and Government Policies. Kluwer Law Internatonal.

[16] Worika, I. L. (2020, June). International Petroleum Policy. Port Harcourt, Rivers State, Nigeria. 